Sudjangi, 1993 Kajian Agama Dan Masyarakat. Departemen Agama RI, Badan Penelitian Dan Pengembangan Agama, Jakarta.

\title{
KEHIDUPAN BERAGAMA MASYARAKAT TRASNMIGRAN ( Studi Kasus Di Desa Sonai Kabupaten Kendari )
}

\author{
Oleh : MUHAMMAD AS AD
}

\section{PEN DAI IU LU AN}

Usaha pembangunan jangka panjang I (PJP I) secara berencana dan bertahap dari pelita (pembangunan lima tahun) ke pelita merupakan pijakan yang sangat penting dalam memasuki PJP II, yang ditandai dengan tahap tinggal landas pada pelita VI. Tahap ini digambarkan sebagai proses mencapai kehidupan bangsa yang lebih baik namun penuh gejolak pembaharuan karena desakan pertumbuhan penduduk, perubahan ekonomi, perkembangan teknologi, persaingan internasional dan perubahan lingkungan hidup.

Sasaran pembangunan jangka panjang yang hendak dicapai bangsa Indonesia, sebagaimana diamanahkan oleh UUD 1945 , adalah terciptanya masyarakat adil dan makmur, sejahtera lahir dan batin. Untuk mencapai sasaran pembangunan nasional tersebut, dalam pembangunan sektor agama selalu ditekankan untuk menumbuhkan regiositas masyarakat yang sekaligus berfungsi sebagai penangkal atau penyaring terhadap dampak pembangunan. Berkaitan dengan itu, pembangunan sektor agama diarahkan untuk mencapai tiga kondisi ideal, yaitu : kadar keimanan dan ketakwaan yang tinggi; wawasan keberagamaan yang luas dan matang; dan kerukunan kehidupan keberagamaan yang mantap dan dinamis untuk menyukseskan pembangunan.

Hasil pembangunan keagamaan yang "dicapai tercermin dalam kehidu-pan masyarakat dan merupakan dasar pertimbangan untuk menentukan lang-kah dan kebijksanaan pembangunan berikutnya. Karena itu corak dan bentuk kehidupan beragama suatu masyarakat perlu diketahui dalam rangka pembangunan masyarakat itu dan masyarakat yang memiliki persamaan dengannya. Informasi yang akurat dari kehidupan beragama suatu masyarakat dapat dilacak lewat penelitian yang memenuhi syarat.

Menyadari luas dan kompleksnya kehidupan beragama suatu masyarakat, 
karena berkaitan dengan berbagai aspek kehidupan lainnya, masalah penelitian ini dirumuskan dalam 4 pertanyaan pokok, yaitu : 1. bagaimana bentuk dan fungsi institusi agama yang ada, 2. bagaimana pola-pola akulturasi dan inkulturasi agama melalui berbagai bentuk pendidikan, 03 . bentuk-bentuk penerangan agama yang bagaimana yang berkembang dan dibutuhkan masyarakat, dan 4. literaturliteratur keagamaan apa yang banyak dibaca dan dibutuhkan masyarakat.

Penelitian yang dilakukan di Desa Sonai, kecamatan Lambuya, Kabupaten Kendari merupakan salah s»**i studi kasus diantara sekian banyak studiserupa yang dilakukan di berbagai komunitas. Pengumpulan data dan informasi dilakukan dengan memakai teknik wawancara mendalam dengan tokoh-tokoh masyarakat dan tokoh-tokoh agama serta segenap pejabat formal. Selain itu juga dilakukan pengamatan intesif terhadap kehidupan sosial dan keagamaan yang empirik ditambah dengan studi dokumen dan kepustakaan. Data yang terkumpul diolah dan dianalisis secara kualitatif dengan deskriptif interpretatif.

\section{GAMBARAN UMUM DESA SONAI}

\section{A. Lingkungan Hidup.}

Desa Sonai adalah salah satu desa yang termasuk Lambuya Selatan, Kecamatan Lambuya dan berada pada jalan poros menuju desa-desa yang berada pada sebelah selatannya. Desa ini berada pada jarak $9 \mathrm{~km}$ dari Kelurahan Lambuya, ibukota kecamatan, $20 \mathrm{~km}$ dari Unaaha, ibukota kabupaten dan $90 \mathrm{~km}$ dari kota Kendari, ibukota propinsi Sulawesi Tenggara.
Luas desa berdasarkan data pada kantor Desa Sonai adalah 2700 ha, sedang menurut BPN kecamatan Lambuya adalah 5879 ha, perbedaan ini kemungkinannya, antara lain disebabkan batas desa pada rawa dan hutan yang tidak jelas. Dari luas desa tersebut, lahan yang dapat dimanfaatkan oleh penduduk masih sangat terbatas, sebagaimana yang tercatat pada laporan kantor desa Sonai (1991) yaitu 663 ha, terdiri atas : sawah 310 ha, perladangan 141 ha, perkebunan rakyat 100 ha, dan pekarangan/pemukiman 112 ha. Masih banyak tenah-tanah milik yang belum dimanfaatkan oleh penduduk, terutama yang merupakan lahan kering, mereka membiarkannya ditumbuhi rumputan liar.

Daerah persawahan kebanyakan berada pada bagian utara desa. Lahan persawahan ini mendapatkan air dari irigasi yang telah dibangun oleh pemerintah sejak tahun 1988. Pembukaan sawah-sawah baru dilakukan oleh petani dengan membuka areal yang dapat memperoleh air dari irigasi tersebut. Bagian selatan desa topografinya bergelombang, pada umumnya berupa lahan kering yang dimanfaatkan sebagai areal perkebunan. Di sela-selanya terdapat lahan kerendahan yang dimanfaatkan sebagai lahan persawahan.

Para petani menanami lahan kebunnya dengan berbagai tanaman, terutama jambu' mente, kelapa dan pisang. Jarang mereka yang menanami sela-selanya dengan tanaman jangka pendek, seperti jagung dan ubi-ubian karena babi hutan senantiasa mengganggunya. Populasi babi hutan di sekitar desa Sonai diperkirakan cukup besar, hal ini didukung oleh lingkungan alam yang memungkinkan. Selain masih banyak areal hutan, juga lahan-lahan penduduk banyak yang belum diolah 
sehingga ditumbuhi belukar dan rumput liar lainnya yang cukup tinggi.

Sebelum daerah ini dihuni oleh penduduk transmigrasi, penduduk asli (suku Tolaki) memanfaatkannya sebagai daerah perladangan (peladang berpindah). Mereka membuka ladang pada beberapa lokasi yang merupakan lahan kering. Sedang rawa-rawa ditumbuhi oleh pohonpohon sagu sebagai salah satu sumber makanan mereka.

Oleh karena daerah ini ditetapkan sebagai lokasi transmigrasi. maka diambil alih dari mereka kecuali beberapa hekto are yang dipertahankan oleh salah seorang dari mereka, yang diakuinya sebagai miliknya. Areal yang dipertahankan itu dikelilingi oleh areal transmigrasi, dan sampai sekarang ia tetap menempati dan menguasai lahan itu.

Pindah tangan pemilikan tanah di Desa Sonai sudah banyak terjadi, baik antara transmigran itu sendiri maupun dengan orang luar. Lahan yang belum terbagi (lahan kelebihan) dan lahan yang ditinggalkan begitu saja diarahkan oleh pemerintah desa keapada orang yang membutuhkan, yaitu pecahan keluarga dan pendatang baru.

Ada di antara keluarga transmigran yang meninggalkan lahan yang menjadi bagiannya setelah tinggal selama satu tahun karena jatah dari Departemen Transmigrasi sudah berakhir. Ada juga yang pindah sesudahnya karena tidak tahan menghadapi tantangan alam atau karena memandang ada daerah lain yang lebih baik.

Konflik pemilikan tanah yang menonjol terjadi antara transmigran dengan penduduk asli yang tingga di desa sekitarnya. Lahan-lahan sagu yang semula ditetapkan sebagai bagian beberapa keluarga transmigran diambil alih oleh penduduk asli dari desa lain, seperti dari desa Puriala. Hal itu terjadi antara lain karena keterlambatan transmigran menggarap lahannya. Di samping itu penduduk asli masih merasa berhak atas pohon-pohon sagu yang ada sebagai milik turun-menurun dari nenek moyang mereka dan menganggap pemerintah belum memberinya ganti rugi. Konflik demikian perlu penanganan tuntas untuk menghindari terjadinya konflik pisik antaranya.

\section{B. Sejarah Dan Administrasi Desa}

Desa Sonai adalah unit pemukiman transmigran yang ditempatkan oleh pemerintah Pusat sejak penghujun tahun 1979. Mereka berasal dari beberapa kabupaten di Jawa Barat ditambah dengan dari DKI Jakarta serta penduduk asli daerah. Mereka terdiri atas $400 \mathrm{kk}$, di antaranya $40 \mathrm{kk}$ penduduk asli daerah yang dikenal dengan APPDT.

Kebijaksanaan mengikut sertakan penduduk asli sebesar $10 \%$ dilandasi oleh suatu tujuan strategis yaitu akulturasi budaya. Kenyataan yang ada meleset dari tujuan itu. Kebanyakan dari APPDT meninggalkan lokasi pemukiman setelah berlalu setahun karena jatah/jaminan dari pemerintah sudah berakhir. Sama halnya dengan di antara transmigran dari DKI Jakarta, karena kebanyakan mereka berlatar belakang "ekonomi pasar" tidak berhasil merobah pola pikir menjadi "ekonomi petani" banyak juga antara mereka yang meninggalkan lokasi transmigran.

Nama Sonai diambil dari salah satu nama-nama tempat yang dipakai penduduk sebelumnya, hanya saja sejarah Sonai (versi lama) tidak didapatkan informasinya. Yang jelas Sonai (versi baru) setelah menjadi desa akan mencatat sejarah baru. 
Mulai dari penghujung 1979 atau awal 1980 sampai tahun 1987 Sonai berada di bawah pembinaan Departemen Transmigrasi. Pada tahun 1987 diserahkan sepenuhnya kepada Departemen Dalam Negeri yang selanjutnya dibagi menja-di dua desa yang definitif, yaitu : Desa Sonai dan Desa Poanaha. Pada tahun itu juga di Desa Sonai diadakan pemilihan kepala desa yang definitif dan K. Slamet Suharjo selaku kordinator/pejabat kepala desa sebelumnya tampil kembali sebagai pemenang, Dengan demikian pada tanggal 15 Juli 1987 ia dilantik sebagai kepala desa pertama yang definitif.

Untuk kelancaran mekanisme administrasi desa, kepala desa Sonai dibantu oleh seorang sekretaris dan lima orang kepala urusan yang melaksanakan tugasnya di bawah kordinasi langsung sekretaris desa. Wilayah desa dibagi atas tiga dusun, yaitu : Dusun I Moromai Moroa, dusun II Iwoi Muala dan dusun III Watusa. Ketiga dusun tersebut dipimpin masing-masing oleh seorang kepala dusun. Selanjutnya ketiga dusun itu dibagi menjadi enam RK dan 17 RT.

Kepala desa, karena jabatannya, merangkap sebagai ketua Lembaga Musyawarah Desa (LMD) dan Ketua Lembaga Ketahanan Masyarakat Desa (LKMD). Kepengurusan LMD Sonai (1991) beranggotakan 11 orang dari tokoh formal, tokoh agama dan tokoh masyarakat lainnya. Strukturnya terdiri atas : Ketua, sekretaris, bidang pemerintahan, bidang kemasyarakatan dan bidang pembangunan. Kepengurusan LKMD (1991) terdiri atas : Ketua Umum. ketua I, ketua II, sekretaris, bendahara dan dilengkapi dengan 10 seksi.

Peranan isteri kepala desa sangat menonjol, sebagaimana yang diatur dalam
Keputusan Mendagri No. 225 tahun 1980, selaku ketua tim penggerak PKK di desanya ia menempati seksi PKK dalam LKMD. Bahkan di desa Sonai selain isteri kepala desa sebagai seksi PKK juga dipercayakan sebagai ketua II. Diletakkan isteri kepala desa selaku ketua tim penggerak PKK di desanya dalam LKMD bertujuan untuk menggerakkan partisipasi aktif kaum wanita dalam membangun desanya. Bertitik - tolak dari hal tersebut, di desa Sonai tim penggerak PKK berusaha membina kaum wanita dalam berbagai usaha, antara lain pembentukan 7 kelompok desawisma yang dengannya diharapkan terlaksana 10 program pokok PKK.

Pembinaan PKK secara khirarsis terkordinasi dari atas mengikuti tingkatan administrasi pemerintahan. Dana pembinaan yang bersumber dari atas setiap tahun anggaran yang sampai dikelola langsung oleh PKK tingkat desa relatif sedikit dibanding dengan dana yang diperuntukkan dan dipertanggungjawabkan olehnya. Dana itu sebahagiannya telah dikelola oleh PKK pada tingkatan yang lebih tinggi, meskipun yang memper-tanggung-jawabkannya adalah PKK tingkat desa. Kebijaksanaan seperti ini dikeluhkan oleh PKK tingkat desa karena dinilai kurang tepat guna.

\section{Penduduk Dan Mata Pencaharian}

Menurut data-pada kantor desa Sonai (1991) penduduk berjumlah 1.156 jiwa, terdiri atas laki-laki 521 jiwa (45\%) dan perempuan 635 jiwa (55 \%). Mereka terkelompok dalam 198 rumah tangga atau 208 keluarga. Jika penduduk tersebut dikelompok-kan, maka yang berusia anakanak (0-9) 36,85 \%, rerhaja (10-19) $21,19 \%$, pemuda dan dewasa pertama (2040) $30,28 \%$ dan dewasa kedua dan orang tua (41 ke atas) $11,68 \%$. 
Penduduk yang tergolong sebagai tenaga kerja. yang sangat produktif (2040) berjumlah 350 orang $(30,28 \%)$. Akan tetapi jika digabung-kan dengan tenaga kerja yang cukup produktif (10-19 dan 4156) maka jumlah tenaga kerja yang tergolong produktff 690 orang $(59,69 \%)$. Penduduk yang tercatat termiliki pekerjaan hanya berjumlah 255 orang $(22,06 \%)$. Jika jumlah ini di prosentasekan dengan jumlah dengan jumlah tenaga kerja produktif tersebut (690 orang) maka yang kerja hanya $32,6 \%$. Na'mun demikian, angkaangka ini belumlah dapat menunjukkan data pengangguran di desa Sonai, karena kenyataan dalam masyarakat para wanita tani terlibat langsung dalam usaha pertanian bersama suami dan anakanaknya. Dari ke 255 orang yang tercatat memiliki perkejaan, kebanyakan (200 orang atau $78.43 \%$ ) yang bekerja sebagai petani. Selebihnya ada pegawai/ABRI/ pensiunan, pegawai swasta, pedagang/ pengusaha dan pertukangan.

Pembagian kerja antara laki-laki / suami dengan perempuan / isteri dalam suatu keluarga petani pangan di Sonai pada dasarnya dapat dipolakan dengan langkah-langkah produksi berikut : 1 . pengolahan sawah : laki-laki, 2. pencabutan dan penanaman beni : perempuan, 3. pemeliharaan/penyiangan : laki-laki dan perempuan, dan 4.Panenan : laki-laki dan perempuan.

Penduduk desa Sonai yang berpendidikan SD sebanyak 120 orang, SLTP 40 orang, SLTA 90 orang dan Sarjana/ Sarjana muda 2 orang. Selain itu ada juga keluaran pesantren dan pendidikan keagamaan lainnya sejumlah 20 orang, dan selebihnya tergolong tidak / belum tamat sekolah Dasar.

Jika penduduk desa Sonai dilihat dari daerah asal/etnik maka yang paling banyak adalah yang berasal dari Jawa Barat, yaitu 167 rumah tangga. Kebanyakan mereka memakai bahasa Jawa dalam kehidupan sehari-hari dan selebihnya memakai bahasa Sunda. Penduduk yang berasal dari DKI Jakarta sisa 7 rumah tangga dan penduduk asli (Suku Tolaki) hanya 14 rumah tangga. Selain itu ada juga pendatang dari Sulawesi Selatan (Bugis Makassar) 10 rumah tangga.

\section{Kepemimpinan, Penggolongan Dan Pelapisan Sosial.}

Sebagaimana pada desa-desa lainnya, kepemimpinan masyarakat di desa Sonai pada dasarnya dapat dibedakan dalam dua jenis. yaitu pemimpin formal dan non formal. Kedua jenis kepemimpinan yang ada itu pada sisi lain dapat digolongkan sebagai kepemimpinan rasional, yaitu kepemimpinan yang di dasarkan pada kondisi yang obyektif, bukan kepemimpinan yang karismatik yang mengandalkan karisma/kesaktian, dan bukan pula kepemimpinan tradisional yang berdasarkan keturunan.

Tampilnya seseorang sebagai pemimpin, masyarakat terkadang tidak hanya ditentukan oleh satu faktor obyektif saja akan tetapi bersifat kumulatif dari dua atau lebih faktor sekaligus. Orang-orang yang' memiliki satu atau lebih kelebihan obyektif, seperti pendidikan, pengetahuan agama atau kemampuan materi secara berangsurangsur akan tampil di tenga-tengah masyarakat dan mendapatkan pengakuan sejalan dengan integritas sosial yang berlangsung.

Pada kenyataannya dalam masyarakat Sonai, orang yang menduduki jabatan penting dalam suatu lembaga desa 
( lembaga pemerintah, semi pemerintah dan kemasyarakatan ) adalah orang-orang yang ditokohkan oleh masyarakat. Figur yang populer dalam masyarakat ada yang menduduki jabatan lebih dari satu, seperti di LKMD dan di LMD.

Kekompakan perangkat desa di bawah kepemimpinan kepala desa sangat menonjol di Sonai. Mereka senantiasa bersama-sama dalam berbagai kegiatan, baik bersifat pemerintahan, kemasyarakatam maupun keagamaan. Tokoh-tokoh pendidik daiam hal ini, guru-guru yang bertugas di Sonai tidak banyak tampil sebagai pemimpin masyarakat. Kebanyakan mereka bertempat tinggal di luar desa dan kedatangannya di desa terbatas sebagai pengajar di sekolahnya.

Di desa Sonai orang yang memiliki pengetahuan yang cukup di bidang agama (Islam) mendapat tempat tersendiri di tengah masyarakat. Selain mereka sebagai pemuka agama juga se sebagai pemuka masyarakat. Kerja sama antara pemimpin formal dan pemuka agama dalam pembinaan masyarakat pada dasarnya terjalin dengan baik, meskipun konflik dibagi secara perorangan tetap ada.

Kelompok masyarakat berdasarkan daerah asal / kesukuan diusahakan lebur dalam integrasi sosial dengan menghindari pengelompokan teritorial, namun hal itu tidak menghilangkan sama sekali kelompok seasal itu. Kegotong royongan diantara mereka sangat kental. Batas antara kelompok-kelompok masyarakat tidak terlalu kentara, kerja sama dan saling bantu antara orang-orang yang tidak seasal berlangsung dengan baik.

Dalam tatanan kehidupan masyarakat di Sonai, yang menduduki strata atas adalah pemimpin formal, tokoh agama, or- ang kaya dan orang yang berpendidikan cukup. Sedangkan yang menduduki strata paling bawah adalah petani miskin yang pendidikari dan pengetahuan agamanya kurang (sistem pelapisan terbuka).

\section{KEHIDUPAN BERAGAMA} MASYARAKAT

\section{A. Pendidikan Agama}

Mayoritas penduduk Sonai menganut agama Islam. Dari 1.156 jiwa penduduk yang beragama Islam sebanyak 1.143 orang $(98,96 \%)$, sedang yang beragama kristen Protestan hanya 13 orang $(1,04 \%)$ dari 3 rumah tangga. Jika penduduk non Islam itu dilihat dari daerah asalnya, nampak bahwa 2 rumah tangga adalah suku tolaki dan lainnya suku toraja (SulSel).

Seperti pada masyarakat Islam lainnya, pendidikan agama pertama-tama diberikan kepada anak lewat rumah tangga, lewat perintah-perintah larangan-larangan dan keteladanan. Bentuk pendidikan ini sangat informal, bergantung pada situasi dan kondisi keagamaan keluarga/ lingkungan anak itu. Pendidikan agama selanjutnya bersifat informal berupa pengajian Al-Qur'an dan formal lewat sekolah.

Sarana pendidikan formal yang ada didesa Sonai sudah terbilang cukup menurut ukuran desa. Sekolah yang ada mulai dari tingkat taman kanak-kanak sampai tingkat sekolah lanjutan pertama, sebanyak 4 buah dengan jumlah murid 301 orang. Sejak tahun ajaran 1987/1988 di Sonai telah didirikan sebuah taman kanakkanak dengan nama TK Tunas Harapan Baiturrahman dibawah asuhan yayasan Baiturrahman. Pada tahun ajaran 1991/ 1992 murid yang diasuh berjumlah 25 orang. Pendidikan Agama yang diberikan 
kepada murid-murid pada umumnya bersifat bimbingan budi pekerti, disamping bacaan-bacaan keagamaan, seperti doa-doa pendek untuk dihafal.

Sekolah dasar yang ada di Sonai 2 unit yang didirikan berbarengan denganberdirinya pemukiman di Sonai ini. SD No.l Sonai yang berlokasi dipusat desa pada tahun ajaran 1991/1992 menampung murid sebanyak 123 orang dengan 9 orang guru, salah seorang diantaranya guru agama (Islam). SDNo.3 Sonai yang bertempat di dusun HI pada tahun ajaran 1991/1992 menampung murid sebesar 86 orang, diantaranya ada yang berasal dari desa Puanaha, dengan jumlah guru hanya 5 orang. Sejak tahun ajaran 1990/1991 sekolah ini tidak memiliki guru bidang studi agama (Islam). Sementara menunggu penempatan guru agama yang baru, kepala sekolah, yang pernah belajar pada PGA sampai kelas IV, melaksanakan tugas guru agama. Waktu yang tersedia untuk pelajaran agama dirasakan kurang untuk menyelesaikan kurikulum yang tersusun, dan lebih dipersempit lagi dengan keterbatasan buku pegangan. Hal ini dirasakan pada kedua sekolah dasar tersebut.

SMP Swasta yang ada di Sonai berada dibawah asuhan yayasan Baiturrahman yang didirikan oleh Masyarakat Sonai, dan sebagai langkah strategis ia bekerja sama dengan PGRI dan diberi nama SMP PGRI Sonai. Namun kenyataanya keterlibatan organisasi profesi ini secara langsung dalam pengelolaanya hampir tidak ada. Pada tahun ajaran 1991/ 1992 sekolah ini menampung siswa sebanyak 67 orang yang terkelompok dalam 3 kelas. Guru yang mengasuh siswa sebanyak 8 orang, 4 diantaranya tenaga honorer dari guru-guru SD sedang 4 lainnya tenaga dari yayasan.

Guru yang dipercayakan mengasuh bidang studi agama pada SMP tersebut adalah pengasuh dari Panti Asuhan Baiturrahman. Latar belakang pendidikannya adalah tamatan SMEA, hanya saja sebelumnya ia merupakan tamatan Madrasah Ibtidaiyah. Dengan demikian secara profesional kemampuannya relatif kurang.

Beberapa tahun yang lalu di Sonai telah didirikan Madrasah Ibtidaiyah swasta dibawah asuhan yayasan Baiturrahman. Setelah berjalan beberapa tahun, Madrasah ini berhenti dari kegiatannya sebelum berhasil menamatkan murid. Madrasah ini memiliki gedung sendiri bantuan dari Departemen agama. Untuk memanfa-atkan gedung itu direncanakan pendirian Madrasah Diniyah Awaliyah (MDA) untuk menampung murid-murid SD pada sore harinya.

Panti Asuhan Baiturrahman di desa Sonai merupakan panti yang mengarah pada pesantren. Andilnya dalam menanamkan pendidikan agama pada anakanak, khususnya anak-anak panti cukup besar. Pendidikan agama yang diberikan kepada anak panti berupa pelajaran mambaca Al-Qur'an, dasar-dasar agama, dasar-dasar bahasa Arab dan latihan da'wah. Pada tahun 1991 panti asuhan ini. mengasuh anak sebanyak 59 orang, lakilaki 34 orang dan perempuan 25 orang. Mereka barasal dari berbagai suku, yaitu: Jawa, Sunda,Tolaki dan Bugis Makassar. Anak-anak Panti yang sudah mencapai usia sekolah mengikuti pendidikan formal di luar panti, baik di tingkat SD maupun SMP.

Pendidikan agama juga diberikan kepada anak-anak lewat pengajian di mesjid dan langgar yang ada di Sonai 
ini.Pada pengajian ini, selain anak-anak diajar membaca Al Qur'an juga diajar dasar-dasar agama, seperti rukun iman, rukun Islam dan pesalatan. Metode belajar yang dilakukan adalah sistem hafalan. Yang diikuti dengan penjelasan kadangan materi yang dihafal itu.

Pengajian ibu-ibu yang dibina olah Pak Da'i (Da'i pembangunan yang ditempatkan oleh Rabithah Alam Islamy) bekerja sama dengan tim penggerak PKK desa Sonai merupakan wadah tempat belajar agama bagi ibu-ibu. Hafalan dengan lagu berbagai materi pelajaran agama sekali-sekali dilakutan. demikian pula pembacaan Al- Qur'an. Selain itu ceramah agama menjadi acara rutin/acara pokok. Yang sama dengan pengajian ibuibu ini ialah pengajian bapak-bapak yang berkumpul sekali seminggu, biasanya pada malam jum'at. Acara utama pada pengajian ini ialah yasinan dan tahlilan, namun ceramah agama merupakan acara yang mengikutinya selama ada da'i/ulama yang hadir.

\section{B. Da'wah Agama.}

Di desa Sonai terdapat 3 buah masjid yang masing-masing terdapat pada 3 dusun yang ada. Masjid ini selain sebagai pusat ibadah juga sebagai pusat da'wah islamiyah. ketiganya ditempati shalat Jum'at. Hanya saja jumlah jamaah yang hadir jauh tidak seimbang dengan jamaah yang semestinya. Khutbah Jum'at sebagai da'wah billisan dilakukan secara bergantian oleh beberapa orang, meskipun dengan kemampuan yang sangat terbatas. Banyak khatib yang membawakan khutbah dengan membaca teks khutbah yang telah diterbitkan.

Di Sonai terdapat dua orang keluaran pesantren yang dapat digolongkan sebagai ulama/kiyai oleh masyarakat. Pada saat penelitian datang seorang lepasan pesantren dari jawa yang dipersiapkan sebagai salah seorang pengajar agama pada panti asuhan. Jika ia betah tinggal di desa ini bertambahlah jumlah da'i yang patut diperhitungkan.

Tingginya frekwensi da'wah islamiyah di desa sonai suatu hal yang wajar, bahkan semestinya. Selain karena adanya ulama, sebagaimana telah disebutkan, juga sejak lama telah ditempatkan seorang da'i yang dapat dikatakan profesional, dalam arti punya perhatian dan tanggung jawab penuh dalam pelaksanaan da'wah islamiyah di desa ini. Pa' Da'i (istilah akrab dalam masyarakat) adalah seorang sarjana muda hukum Islam dan mempunyai keterampilan berda'wah yang memadai.

Kegiatan da'wah sekaligus sebagai kegiatan pendidikan yang berlangsung pada setiap masjid cukup banyak, seperti pengajian anak-anak, kegiatan remaja masjid dan pengajian ibu-ibu. Pada setiap masjid telah terbentuk wadah remaja masjid. Kegiatan yang biasa dilakukan antara lain : pelatihan da'wah dan pengajian secara insidental.

Sebagai wadah da'wah, pengajian bagi bapak-bapak telah terbentuk pada setiap dusun, namun yang aktif hanya kelompok yasinan di dusun I dan kelompok berzanji di dusun II. Kegiatan kelompok tersebut sekali seminggu pada tempat $y$-:ng berpindah-pindah dari satu rumah ke rumah lain dari anggotanya. Sebagai medya da'wah, dalam pengajian ini dapat terbina jiwa dan rasa keagamaan serta kecintaan kepada Rasulullah. Di samping itu dapat menambah pengetahuan dan wawasan agama dengan pengisian ceramah-ceramah agama.

Wada da'wah lainnya yang aktif ialah 
pengajian ibu-ibu yang terbentuk pada setiap dusun dan berpusat di masjid. Majelis Ta'lim ini mengadakan pengakian sekali seminggu. Acara inti dalam pengajian ialah mendengarkan ceramah/ bimbingan agama. Acara lain yang biasa juga dilakukan dalam pengajian adalah simulasi P4.

Di desa Sonai da'wah islamiyah bentuk ceramah agama sering dilakukan dalam berbagai peluang dan kesempatan, seperti dalam upacara/selamatan. Masyarakat kurang puas bila menghadiri suatu selamatan tanpa adanya ceramah agama. Kegiatan da'wah berkaitan dengan upacara / selamatan merupakan hal yang biasa di desa-desa di Jawa Barat (lihat Ahmad Tafsir 1991).

Sebagaimana di tempat-tempat lain yang penduduknya mayoritas beragama Islam, penduduk Sonai senantiasa merayakan hari-hari besar Islam. Semua upacara itu berpusat di masjid dan dilakukan secara bersama-sama. Shalat Hari raya dilakukan di masjid dan dihadiri jamaah yang cukup banyak. Kesemarakkan lebih nampak pada hari raya/idui Fitri dibanding hari raya idul adha.

Upacara yang tetap dilestarikan oleh masyarakat Sonai. sebagai pelestarian budaya asalnya (Jawa Barat) ialah upacara pada bulan syawal. Upacara ini senantiasa dilakukan oleh masayarakat di dusun I dan di dusun III dengan tempat yang berbeda, masing-masing di masjid dan persimpangan jalan. Meskipun sejarah timbulnya upacara ini, menurut seorang informan, berasal dari cerita pewayangan, sebagai persembahan kepada Bumi. Namun pemanfaatannya sebagai medya da'wah sangat menguntungkan, dengan menafasinya dengan Islam.

\section{Lektur Keagamaan}

Di desa Sonai toko buku belum ada dan perpustakaan desa belum di bangun. Yang ada ialah perorangan yang memiliki berbagai macam koleksi buku. Pemilikan buku-buku agama di kalangan masyarakat Sonai cukup merata, hampir semua - kalau tidak dikatakan semua - rumah tangga memiliki buku agama di rumahnya, meskipun sangat terbatas, seperti hanya memilik sebuah Al Qur'an dan sebuah buku lainnya.

Keberadaan Da'i pembangunan di Sonai besar artinya dalam penyebaran lektur keagamaan di kalangan masyarakat. Rabithah Alam Islamy dan Departemen Agama banyak mengirim lektur keagamaan kepadanya. Buku-buku dan majalah yang dikirim kepadanya selain dibaca sendiri juga dipinjamkan kepada masyarakat yang berminat.

Kehadiran Pa'Muhaimin, seorang keluaran pesantren yang diakui masyarakat sebagai kiyai, besar artinya dalam penyebaran lektur keagamaan dalam masyarakat. Ia memiliki koleksi buku-buku agama berupa buku kuning berkaitan dengan berbagai cabang ilmu agama. Meskipun masyarakat tidak dapat membaca buku-buku tersebut, namun mereka dapat mengambil manfaat lewat khutbah/ceramah agama. Hanya saja • pa'kiyai tersebut tidak membuka pengajian kitab bagi masyarakat.

Orang yang memiliki kitab-kitab kuning lainny, meskipun relatif sedikit, ialah pa'Muhid, juga diakui masyarakat sebagai kiyai. Selain itu ia juga memiliki beberapa buku lainnya baik dengan pengantar Arab Pegon maupun Arap Latin.

Kebanyakan buku-buku agama yang dimiliki masyarakat memakai pengantar 
bahasa Indonesia. Buku yang sangat digemari oleh masyarakat Sonai, utamanya para petani, adalah yang memakai pengantar atau terjemah dalam bahasa daerah Jawa atau Sunda. Buku-buku demikian yang dimiliki masyarakat kebanyakan terbitan lama.

Pengajian anak-anak di masjid Annur memakai buku pengantar bahasa Sunda, sedang di masjid Al-Hidayah memakai buku pengantar bahasa Jawa. Buku-buku yang dipakai merupakan buku kecil yang memuat dasar-dasar Islam, seperti buku perukunan Gde (bahasa Sunda tulisan Arab).

Buku keagamaan yang cukup beragam dimiliki masyarakat adalah bukubuku khotbah jum'at, baik dengan pengantar bahasa Indonesia maupun bahasa Jawa. Buku-buku tersebut biasanya dibacakan khatib pada khutbah-khutbah Jum'at. Seperti susunan M. Farid Anwar, BA, Drs. Imran Abu Amar, H. A. Mustofa, M. Zakaria Idris dan SE. Zainal Abidin.

\section{Pola Kepemimpinan Agama}

Seperti telah dikemukakan, kerja-sama antara pemimpin formal dengan pemimpin agama erat sekali sehingga tidak terlihat adanya garis pemisah antara keduanya. Di antara pemimpin formal terkadang tampil sebagai pemimpin agama, misalnya sebagai khatib Jum'at. pa'Da'i sebagai tokoh agama sekaligus sebagai tokoh masyarakat yang senantiasa dipercayakan pada suatu posisi penting dalam organisasi / kelembagaan desa.

Kepemimpinan di desa Sonai cenderung terpusat pada dua figur yang mampu menjalin kerjasama yang baik, kepala desa selaku pemimpin formal dan pa' Da'i selaku pemimpin agama (non formal). Kedua tokoh agama lainnya (pa'kiyai) lebih banyak tampil sebagai tokoh masyarakat yang bersifat informal, seperti memimpin upacara/selamatan dan memberikan bimbingan agama secara insidental.

Tokoh agama yang dapat dikatakan menduduki level yang lebih rendah dari mereka yang telah disebutkan, adalah guruguru mengaji yang membuka pengajian $\mathrm{Al}$ Qur'an di masjid dan langgar. Pengaruhnya terbatas pada lingkungan di mana mereka tinggal. Mereka juga berfungsi sebagai imam *shalat di masjid, meskipun tidak populer dengan predikat iman atau pegawai Syara seperti di Sulawesi Selatan (baca Badrum, 1991 : 39-95).

Baik imam desa maupun pembantu PPN di Sonai (dijabat dua orang) selaku aparat agama, dalam hal ini menangani beberapa kepentingan keagamaan masyarakat, tampil di tengah-tengah masyarakat lebih banyak sebagai aparat formal, misalnya dalam urusan perkawinan dan perceraian, ketimbang sebagai tokoh/ pemimpin agama.

\section{KESIMPULAN}

Desa Sonai, sebagai pemukiman transmigran yang mayoritas berasal dari Jawa Barat, cenderung sebagai desa Jawa Barat di luar Jawa. Kehidupan sosial dan keagamaan masyarakat tidak jauh beda dengan desa-desa di Jawa Barat, baik dilihat dari kegotong-royongan mereka maupun dari sistim pembagian kerja antara laki-Iaki dan perempuan. Sebagai masyarakat desa, pemimpin formal dan 
pemimpin agama sulit dipisahkan secara ketat dan kepemimpinan terpusat pada orang-orang tertentu.

Sebagai desa yang mayoritas penduduknya beragama Islam, dilihat dari sisi kelembagaan, aktivitas keagamaan masyarakat cukup menggembirakan. Demikian halnya dari sisi ketokohan atau sumber daya manusia yang handal dibidang agama. Hanya saja fungsionalisasi tenaga yang handal itu belum maksimal yang berakibat ketaatan beragama secara menyeluruh nampaknya belum mencapi tarap yang menggembirakan.

Berdirinya yayasan Baiturrahman, sebagai milik masyarakat Sonai, merupakan suatu terobosan yang sangat positif. Kiprahnya sangat strategis dalam rangka pembangunan masyarakat. Usaha-usaha yang dilakukan, baik dibidang pendidikan maupun penyantunan anak yatim dan anak terlantar sangat ideal. Namun demikian, karena keterbatasan yang dimiliki. maka memerlukan bantuan dan partisipasi dari luar agar dapat berkiprah secara maksimal sesuai harapan masyarakat.

\section{DAFTAR BACAAN}

Astrid S. Susanto, DR phil : Pengantar

1985 Sosiologi dan Perubaban Sosia^ cetakan kelima, Bina Cipta.

Ahmad Tafsir, DR, dkk : Konfigurasi

1991 Kehidupan Agama Menjelang Tinggal Landas Pembangunan Nasional di Kecamatan Cileunyi Kabupaten Bandung propinsi Jawa Barat, laporan penelitian, Jakarta : proyek penelitian
Keagamaan Badan Penelitian dan pengembangan Agama Departemen Agama.

Badrum, Drs., pat. Ma, : Prospek

1991 Pengembangan Syara' dalam proses Alih peran KB Mandiri di Sulawesi Selatan, Lapuran penelitian, Ujung Pandang : BKKBN kerja sama dengan FISKAL.

Balai penelitian Lektur Keagamaan ujung 1987 Pandang : Masuknya Islam di Sulawesi Tenggara, Laporan Hasil penelitian, Ujung Pandang.

Soerjono, Soekanto : Sosiologi, suatu

1982 Pengantar, edisi baru kesatu, Jakarta : CV Rajawali.

Tarimana. A. Rauf : Kala Sebagai Fokus 1985 Kebudayaan Tolaki, Disertai, Jakarta : Universitas Indonesia 